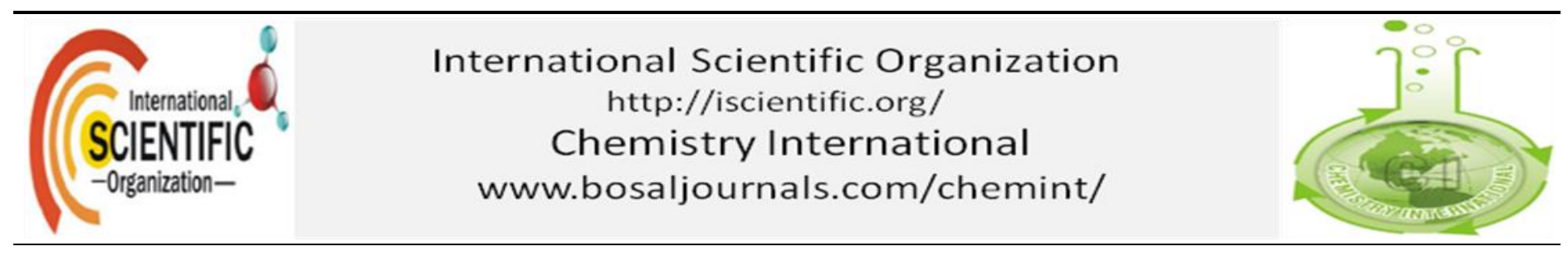

\title{
Metal contents in traditional chewing sticks commonly used in Ethiopia: A comparative analysis
}

\author{
Wubalem Entele and Bhagwan Singh Chandravanshi*
}

\author{
Department of Chemistry, College of Natural and Computational Sciences, Addis Ababa University, P.O. Box 1176, Addis \\ Ababa, Ethiopia \\ *Corresponding author's E. mail: bscv2006@yahoo.com
}

\section{A R T I C L E I N F O A B S T R A C T}

\section{Article type:}

Research article

Article history:

Received December 2020

Accepted March 2021

July 2021 Issue

Keywords:

Chewing sticks

Traditional toothbrushes

Salix subserrata

Sidacuneifolia

Clausenaanisate

Metal contents

Ethiopia
African toothbrush sticks have been used for centuries for the maintenance of oral hygiene. This is especially true in developing countries where economics, customs, religion and the availability of oral hygiene tools play a role in their continued use. Chewing sticks are used by the majority of the population in Ethiopia. The aim this study was to determine the levels of essential and non-essential metals in chewing sticks from three plants (Salix subserrata, Sida cuneifolia and Clausena anisata) in samples collected from three selected areas (Muger, Sendafa and Holleta) of Ethiopia. Samples were wet digested with mixture of $\mathrm{HNO}_{3}$ and $\mathrm{HClO}_{4}$ at optimized temperature and time. The levels of metals were determined by microwave plasma-atomic absorption spectrometry. The range of mean concentrations of the metals $(\mathrm{mg} / \mathrm{kg})$ in the $S$. subserrata, S. cunnefolia, and C. anisata samples were in the order of $\mathrm{Ca}(14150-25914)>\mathrm{Fe}(514-1191)>\mathrm{Al}(103-1263)>\mathrm{Zn}(152-196)>$ $\mathrm{Mg}(46-102)>\mathrm{Ni}(4-160)>\mathrm{Mn}(25-78)>\mathrm{Cu}(13-20)>\mathrm{Cr}(7-8)$. The accuracy of the optimized procedure was evaluated by analyzing the digest of the spiked samples with standard solution and the percentage recoveries varied from $92 \%$ to $104 \%$. The toxic metals $\mathrm{Cd}$ and $\mathrm{Pb}$ in the plant samples were not detected. Thus, people using "chewing stick" from studied plants are free from the risks of $\mathrm{Cd}$ and $\mathrm{Pb}$ toxicity.

(C) 2021 International Scientific Organization: All rights reserved.

Capsule Summary: The essential and non-essential metals in chewing sticks collected from three plants (Salix subserrata, Sida cuneifolia and Clausena anisata) from three Ethiopion areas (Muger, Sendafa and Holleta) were determined and Cd and $\mathrm{Pb}$ were not detected in the chewing sticks of Ethiopia.

Cite This Article As: W. Entele and B. S. Chandravanshi. Metal contents in traditional chewing sticks commonly used in Ethiopia: A comparative analysis. Chemistry International 7(3) (2021) 163-171.

https://doi.org/10.5281/zenodo.4899171

\section{INTRODUCTION}

There is a long history of the use of plants to improve dental health and promote oral hygiene and is still commonly practiced among Afro-Asian communities. Pencil sized sticks are fashioned from certain plant parts and are chewed on one end until they become frayed into a brush and the brush end is used to clean the teeth in a similar manner to the toothbrush. The plant parts when used in this manner are commonly referred as the "chewing stick". Their use still continues in the modern era of dentistry. It is inexpensive and easily available in rural areas. Further they are used for customary and religious reasons as well. Dental treatment usually is expensive and not so easily accessible, especially in developing countries, therefore humans have turned to the 
use of tooth sticks/chewing sticks from natural resources to prevent dental caries (Akpata and Akinrimisi, 1977; Homer et al., 1990; Wu et al., 2001).

The most commonly used chewing sticks are those having a good flavor, texture and a recognized effect on the teeth and supporting tissue. Freshly cut specimens are always desirable because they are more easily chewed into a brush. The plants used are very carefully selected for such properties as foaminess, hardness or bitterness and certain species are more popular than others. Popular plants which are fascinated into chewing and/or tooth brushing sticks include Salvadora persica (miswak from arak tree) and Azadirachta indica (Neem) (Almas, 1999). Some of the popular species used as natural toothbrush in Southern-Eastern Africa are Albizia coriaria, Acacia nilotica, Olea europeasubsp. africana, Salix subserrata, etc. In West Africa the lime tree (Citrus aurantafolia) and the orange tree (Citrus sinesis) are used. The roots of senna (Cassia vinnea) were used by black Americans and those of African laburnum (Cassia sieberianba) were used in Sierra Leone (Almas, 2001; Niazi et al., 2016).

There are more than 180 plant species that can be used as a natural toothbrush. These species differ from each other on the basis of appearance, scent, texture and taste (Niazi et al., 2016). Some of the most commonly practiced species are S. persica (Peelu), Azadirachta indica (Neem), Olea europaea (Zaitoon), Acacia arabica (Kikar), Glycosmis pentaphylla (Ban), Capparis aphylla (Khiran). Arak (S. persica) is the most commonly used miswak in Saudi Arabia while litmus and orange tree are common in West Africa S. persica obtained from arak tree is the most popular having spongy characteristics and stem that can easily be crushed between teeth. The stick is widely accepted by people around the world due to its pleasant flavor, texture and its effectiveness in maintaining oral hygiene (Niazi et al., 2016).

African toothbrush sticks have been used for centuries for the maintenance of oral hygiene. Even though many people have abandoned the traditional toothbrush sticks and adapted to the conventional tooth brushing method, some societies still make use of chewing sticks as a daily ritual to maintain oral hygiene. This is especially true in developing countries where economics, customs, religion and the availability of oral hygiene tools play a role in their continued use (Kemoli et al., 2001). Often, chewing sticks are used by the majority of the population, as is the case of Ethiopians (Fadulu, 1975; Olsson, 1978). Although the World Health Organization has promoted the use of toothbrush sticks (Wu et al., 2001) and has encouraged further research of their efficacy, few studies have been undertaken on the potential antimicrobial properties of chewing sticks. Al-hebshi et al. (2006) confirm this in their investigation of crude khat chewing sticks, which have not been investigated previously. Kassu et al. (1999) assessed the most common toothbrush sticks used by rural and urban Ethiopians. Three plant species namely Clausenaanisata, Salix Subserrata and Sida cuneifolia were selected for the present study based on their wider use and availability.
Clausena anisata (Will). Hook.f. ex. benth. is a tropical shrub or tree growing up to ten meters in height and on the margins of evergreen forests. Different parts (stem bark, roots, and leaves) of this plant are widely used in traditional medicine to treat many diseases. Traditional healers in Tanzania use $C$. anisata against oral candidiasis and fungal infections of the skin, whereas in the Temeke district (Daressalam, Tanzania), C. anisata is used against epilepsy and as an anticonvulsant. The various morphological parts of the plant have been identified to be effective remedies against worm infections, respiratory ailments, heart disorders, hypertension, malaria, fever, rheumatism, insanity, convulsion and other inflammatory conditions (Hutchings et al., 1996; Hamza et al., 2006). The concoction of the stem bark and the leaves was also identified to be an effective traditional treatment for tuberculosis during an ethno botanical survey among Xhosa people in the Eastern Cape Province (Lawal et al., 2014). The essential oil in C. anisatahas been reported to be responsible for its several pharmacological activities, including antimicrobial, anti-inflammatory and anti-diabetic properties (Ojewole, 2002; Senthikumar and Venkatesalu, 2009; York et al., 2012).

Sida cuneifolia is a shrub that has a tough woody stem and can grow up to a meter tall if left undisturbed. It has yellow flowers with five distinct petals and five sepals. Its leaves are notched at the tip with smooth margins. Traditionally, $S$. cuneifolia has been used as a herbal remedy to manage up to 12 diseases. In Busoga, Uganda, it is used to disinfect umbilical cord wounds. Among the Sabaot people around Mt. Elgon in Kenya it is known as Kupchuwet and the roots are chewed to treat sore throat. Salix subserrata (Synonyms $S$. safsaf) Wild (Salicaceae) is a deciduous bush or small tree 2-10 m high at stream sides in throughout Africa (Gambia, Egypt, Libyan, Zambia and Sudan). Many curative effects of medicinal herbs used in the phytotherapy are due to the presence of very minute quantities of trace elements. These elements are $\mathrm{Fe}$, $\mathrm{Cu}, \mathrm{Co}, \mathrm{Ni}, \mathrm{Zn}, \mathrm{Mg}, \mathrm{Mn}, \mathrm{Mo}, \mathrm{Cr}, \mathrm{V}, \mathrm{Li}, \mathrm{Se}, \mathrm{F}$ and I. Other heavy metals like $\mathrm{Pb}, \mathrm{Cd}$ and $\mathrm{Hg}$ are toxic at very lower concentration. World Health Organization declares the maximum permissible levels in food and drug materials for As, $\mathrm{Cd}$ and $\mathrm{Pb}$ as amount to $1.0,0.3$ and $10 \mathrm{mg} / \mathrm{kg}$, respectively (Başgel and Erdemoğlu, 2006).

A high supplementation of $\mathrm{Cu}$ had been related with liver damage. $\mathrm{Zn}$ may produce adverse nutrient interactions with $\mathrm{Cu}$. $\mathrm{Zn}$ reduces the immune function and levels of highdensity lipoproteins. Plants may absorb heavy metals from soil, water or air. Medicinal herbs may be easily contaminated during growing and processing. The ability of plants to selectively accumulate essential elements is different for different species and is subjected to certain geochemical characteristics depending on the type of soil. Usually, soil is subjected to contamination through atmospheric deposition of heavy metals from point sources including mining, smelting and different industrial activities (Bin et al., 2001). 
Table 1: Optimization of digestion procedure for $C$. anisata, S. cuneifoliaand S. subserreta samples

\begin{tabular}{|c|c|c|c|c|c|}
\hline Trial & Reagents used & Volume ratio & Temperature $\left({ }^{\circ} \mathrm{C}\right)$ & Digestion time (h) & Observation \\
\hline \multicolumn{6}{|c|}{ C. anisata } \\
\hline 1 & $\mathrm{HNO}_{3}: \mathrm{HClO}_{4}$ & $2: 2$ & 300 & 3 & Light yellow \\
\hline 2 & ${ }^{*} \mathrm{HNO}_{3}: \mathrm{HClO}_{4}$ & $3: 1$ & 300 & 3 & Clear and Colorless \\
\hline 3 & $\mathrm{HNO}_{3}: \mathrm{HClO}_{4}$ & $3: 2$ & 300 & 3 & Clear and Colorless \\
\hline 4 & $\mathrm{HNO}_{3}: \mathrm{HClO}_{4}$ & $3: 3$ & 300 & 3 & Clear and Colorless \\
\hline 5 & $\mathrm{HNO}_{3}: \mathrm{HClO}_{4}$ & $4: 1$ & 300 & 3 & Clear and Colorless \\
\hline 6 & $\mathrm{HNO}_{3}: \mathrm{HClO}_{4}$ & $4: 2$ & 300 & 3 & Clear and Colorless \\
\hline 7 & $\mathrm{HNO}_{3}: \mathrm{HClO}_{4}$ & $3: 1$ & 150 & 3 & Light yellow \\
\hline 8 & $\mathrm{HNO}_{3}: \mathrm{HClO}_{4}$ & $3: 1$ & 180 & 3 & Light yellow \\
\hline 9 & $\mathrm{HNO}_{3}: \mathrm{HClO}_{4}$ & $3: 1$ & 210 & 3 & Light yellow \\
\hline 10 & $\mathrm{HNO}_{3}: \mathrm{HClO}_{4}$ & $3: 1$ & 240 & 3 & Clear and Colorless \\
\hline 11 & $\mathrm{HNO}_{3}: \mathrm{HClO}_{4}$ & $3: 1$ & 270 & 3 & Clear and Colorless \\
\hline 12 & $\mathrm{HNO}_{3}: \mathrm{HClO}_{4}$ & $3: 1$ & 300 & 3 & Clear and Colorless \\
\hline 13 & $\mathrm{HNO}_{3}: \mathrm{HClO}_{4}$ & $3: 1$ & 240 & $1: 45$ & Light yellow \\
\hline 14 & $\mathrm{HNO}_{3}: \mathrm{HClO}_{4}$ & $3: 1$ & 240 & $2: 00$ & Light yellow \\
\hline 15 & $\mathrm{HNO}_{3}: \mathrm{HClO}_{4}$ & $3: 1$ & 240 & $2: 15$ & Clear and Colorless \\
\hline 16 & $\mathrm{HNO}_{3}: \mathrm{HClO}_{4}$ & $3: 1$ & 240 & $2: 30$ & Clear and Colorless \\
\hline 17 & $\mathrm{HNO}_{3}: \mathrm{HClO}_{4}$ & $3: 1$ & 240 & $2: 45$ & Clear and Colorless \\
\hline 18 & $\mathrm{HNO}_{3}: \mathrm{HClO}_{4}$ & $3: 1$ & 240 & $3: 00$ & Clear and Colorless \\
\hline \multicolumn{6}{|c|}{ S. cuneifolia } \\
\hline 1 & $\mathrm{HNO}_{3}: \mathrm{HClO}_{4}$ & $2: 2$ & 300 & 3 & Light yellow \\
\hline 2 & $\mathrm{HNO}_{3}: \mathrm{HClO}_{4}$ & $3: 1$ & 300 & 3 & Light yellow \\
\hline 3 & $\mathrm{HNO}_{3}: \mathrm{HClO}_{4}$ & $3: 2$ & 300 & 3 & Yellowish \\
\hline 4 & $\mathrm{HNO}_{3}: \mathrm{HClO}_{4}$ & $3: 3$ & 300 & 3 & Yellowish \\
\hline 5 & $\mathrm{HNO}_{3}: \mathrm{HClO}_{4}$ & $4: 1$ & 300 & 3 & Clear colorless \\
\hline 6 & $\mathrm{HNO}_{3}: \mathrm{HClO}_{4}$ & $4: 2$ & 300 & 3 & Clear colorless \\
\hline 7 & $\mathrm{HNO}_{3}: \mathrm{HClO}_{4}$ & $4: 1$ & 120 & 3 & Deep yellow \\
\hline 8 & $\mathrm{HNO}_{3}: \mathrm{HClO}_{4}$ & $4: 1$ & 150 & 3 & Yellowish \\
\hline 9 & $\mathrm{HNO}_{3}: \mathrm{HClO}_{4}$ & $4: 1$ & 180 & 3 & Light yellow \\
\hline 10 & $\mathrm{HNO}_{3}: \mathrm{HClO}_{4}$ & $4: 1$ & 210 & 3 & Clear and colorless \\
\hline 11 & $\mathrm{HNO}_{3}: \mathrm{HClO}_{4}$ & $4: 1$ & 240 & 3 & Clear and colorless \\
\hline 12 & $\mathrm{HNO}_{3}: \mathrm{HClO}_{4}$ & $4: 1$ & 270 & 3 & Clear and colorless \\
\hline 13 & $\mathrm{HNO}_{3}: \mathrm{HClO}_{4}$ & $3: 1$ & 210 & $1: 45$ & deep yellow \\
\hline 14 & $\mathrm{HNO}_{3}: \mathrm{HClO}_{4}$ & $3: 1$ & 210 & $2: 00$ & Yellowish \\
\hline 15 & $\mathrm{HNO}_{3}: \mathrm{HClO}_{4}$ & $3: 1$ & 210 & $2: 15$ & Yellowish \\
\hline 16 & $\mathrm{HNO}_{3}: \mathrm{HClO}_{4}$ & $3: 1$ & 210 & $2: 30$ & Light yellow \\
\hline 17 & $\mathrm{HNO}_{3}: \mathrm{HClO}_{4}$ & $3: 1$ & 210 & $2: 45$ & Light yellow \\
\hline 18 & $\mathrm{HNO}_{3}: \mathrm{HClO}_{4}$ & $3: 1$ & 210 & 3:00 & Clear and colorless \\
\hline \multicolumn{6}{|c|}{ S. subserreta } \\
\hline 1 & HNO3:HClO4 & $2: 2$ & 300 & 3 & Light yellow \\
\hline 2 & HNO3:HClO4 & $3: 1$ & 300 & 3 & Clear and colorless \\
\hline 3 & HNO3:HClO4 & $3: 2$ & 300 & 3 & Light yellow \\
\hline 4 & HNO3:HClO4 & $3: 3$ & 300 & 3 & Light yellow \\
\hline 5 & HNO3:HClO4 & $4: 1$ & 300 & 3 & Clear and colorless \\
\hline 6 & HNO3:HClO4 & $4: 2$ & 300 & 3 & Yellowish \\
\hline 7 & HNO3:HClO4 & $3: 1$ & 150 & 3 & Light yellow \\
\hline 8 & HNO3:HClO4 & $3: 1$ & 180 & 3 & Light yellow \\
\hline 9 & HNO3:HClO4 & $3: 1$ & 210 & 3 & Deep yellow \\
\hline 10 & HNO3:HClO4 & $3: 1$ & 240 & 3 & Light yellow \\
\hline 11 & HNO3:HClO4 & $3: 1$ & 270 & 3 & Clear and colorless \\
\hline 12 & HNO3:HClO4 & $3: 1$ & 300 & 3 & Clear and colorless \\
\hline 13 & HNO3:HClO4 & $3: 1$ & 240 & $1: 45$ & Light yellow \\
\hline 14 & HNO3:HClO4 & $3: 1$ & 240 & $2: 00$ & Clear and colorless \\
\hline 15 & HNO3:HClO4 & $3: 1$ & 240 & $2: 15$ & Clear and colorless \\
\hline 16 & HNO3:HClO4 & $3: 1$ & 240 & $2: 30$ & Clear and colorless \\
\hline 17 & HNO3:HClO4 & $3: 1$ & 240 & $2: 45$ & Clear and colorless \\
\hline 18 & HNO3:HClO4 & $3: 1$ & 240 & $3: 00$ & Clear and colorless \\
\hline
\end{tabular}

*The bold font indicates the optimum reagent volume ratio, temperature and time 
Some other sources of soil contamination involve use of fertilizers, pesticides, sewage sludge and organic manures (Singh et al., 1997). Additional sources of these elements for plants are rainfall, atmospheric dusts and plant protection agents, which could be adsorbed through the leaf blades and transported to different plant parts. An important source of contamination, in vegetable crops, is considered to be the foliar uptake of atmospheric heavy metals emissions by the soil (Salim et al., 1993).

In Ethiopia some studies have been done on the mineral contents of medicinal plants such as khat (Atlabachew et al., 2010), thyme (Derbie and Chandravanshi, 2011), Rhamnus prinoides (Gesho) (Gebre and Chandravanshi, 2012), linseed (Mekebo and Chandravanshi, 2014), Croton macrostachyus (Dubale et al., 2015), ginger (Wagesho and Chandravanshi, 2015), Cannabis (Zerihun et al., 2015), fenugreek (Hagos and Chandravanshi, 2016), coriander (Abdella et al., 2018), and Rue (Admasu et al., 2018). However, there is no study on the mineral contents of Ethiopian chewing sticks. Therefore, it is worthwhile to determine the levels of metals in the chewing sticks commonly used in Ethiopia.

The present study is aimed to determine the levels of selected metals ( $\mathrm{Cd}, \mathrm{Cr}, \mathrm{Cu}, \mathrm{Mn}, \mathrm{Ni}, \mathrm{Pb}, \mathrm{Al}, \mathrm{Mg}, \mathrm{Ca}, \mathrm{Fe}$ and $\mathrm{Zn}$ ) in three plant species (S. subserrata, S. cuneifolia and C. anisata) used as toothbrush sticks and to compare the content of heavy metals in the three-plant species from each sampling site and among each other and to compare the content of heavy metals in the three-plant species with the metal contents of tooth pastes.

\section{MATERIAL AND METHODS}

\section{Apparatus and equipment}

Stainless steel axe and Teflon (PTFE) knife were used to cut the plant parts in to pieces while air-circulating oven (Digitheat, J.P. Selecta, Spain) was used for drying the samples placed on porcelain. Ceramic pestle and mortal were used for grinding and homogenizing the samples. Digital analytical balance (Mettler Toledo, Model At250, Switzerland) was used for weighing the samples. Round bottom flasks $(250 \mathrm{~mL})$ fitted with reflux condenser were employed in digesting the sample on Kjeldahl heating apparatus (Gallenkamp, England). Borosilicate volumetric flasks $(50 \mathrm{~mL})$ were used during dilution of sample and preparation of metal standard. Measuring cylinders (Duran, Germany), pipettes (Pyrex, USA) and micropipettes (Dragonmed, 1-10 $\mu \mathrm{L}, 100-1000 \mu \mathrm{L}$, Shangai, China) were used during measuring different quantities of volumes of sample solution, acid reagents and metal standard solutions. Metal contents of the plant samples were determined by microwave plasma-atomic emission spectroscopy (MP-AES) (Agilent model 4200, USA).

\section{Chemical and reagents}

All the reagents used in the present study were of analytical grade. 69.5\% $\mathrm{HNO}_{3}$ (Supreme Enterprises Cantt, India) and
$70 \% \mathrm{HClO}_{4}$ (Aldrich, UK) were used for the digestion of the samples. Stock standard solution of concentration $1000 \mathrm{mg} / \mathrm{L}$ in $2 \% \mathrm{HNO}_{3}$ of the metals $\mathrm{Ca}, \mathrm{Mg}, \mathrm{Mn}, \mathrm{Fe}, \mathrm{Zn}, \mathrm{Cu}, \mathrm{Zn}, \mathrm{Cr}, \mathrm{Ni}, \mathrm{Co}$, $\mathrm{Cd}$ and $\mathrm{Pb}$ (Buck Scientific Puro-Graphictm, USA) were used for the construction of the calibration curve of each metal. Deionized water was used throughout the study.

\section{Description of the study area}

The samples of the selected plants were collected from three regions namely: Holleta, Sendafa and Muger which are smaller cities that are found near to Addis Ababa, the capital city of Ethiopia. The selected areas were based on availability of the plant and their popularity in using as toothbrush plants by the local population.

\section{Sample collection and handling}

Salix subserrata, Sida cuneifolia and Clausena anisata samples were collected from three different sites which are the most common areas from which the sticks that are used for brushing teeth in Addis Ababa. From each plant a known amount of branch stems with leaves samples of $S$. subserrata and $C$. anisata and roots of $S$. cuneifolia, since only the roots of this plant are used as chewing sticks were collected. The samples were kept in polyethylene bags and transported to the laboratory. Unwanted materials such as leaves and very tiny roots were removed but the barks were included in the sample because that is how the chewing sticks are prepared. The stems and roots of the plants were washed well with the running tap water and rinsed first with distilled water and then with deionized water to remove earthly impurities, allowed to dry in air for ten days, chopped and grounded to powder with mortar and pestle. The powdered samples were sieved to $0.425 \mathrm{~mm}$ mesh size and stored in dry, clean and closely packed polyethylene plastic bag until digestion. Finally, $0.5 \mathrm{~g}$ aliquot was taken from each sample for digestion.

\section{Optimization of digestion procedure}

To select an optimum procedure for digestion, parameters like digestion time, volume ratio of reagents, and digestion temperature were optimized by varying one parameter at a time and keeping the others constant. Parameters giving clear solution at lower temperature, requiring minimum reagent volume and digestion time were selected as an optimum procedure for digestion of the three plant samples. Finally, the optimum procedure was chosen for each sample. The results of optimization of digestion are summarized in Table 1.

\section{Digestion of samples}

Applying the optimized procedure given above, $0.5 \mathrm{~g}$ of powdered sample of $C$. anisata, $S$. cuneifolia and $S$. subserreta were transferred to $250 \mathrm{~mL}$ round bottom flasks, respectively. To these, $3 \mathrm{~mL}$ of $\mathrm{HNO}_{3}$ and $1 \mathrm{~mL}$ of $\mathrm{HClO}_{4}, 4 \mathrm{~mL}$ of $\mathrm{HNO}_{3}$ and 
$1 \mathrm{~mL}$ of $\mathrm{HClO}_{4}$ and $3 \mathrm{~mL}$ of $\mathrm{HNO}_{3}$ and $1 \mathrm{~mL}$ of $\mathrm{HClO}_{4}$, respectively, were added. The round bottom flasks were fitted to reflux condensers and heated on a Kjeldahl apparatus hot plate for $2: 15 \mathrm{~h}$ at temperature of $240{ }^{\circ} \mathrm{C}, 3 \mathrm{~h}$ at temperature of $210{ }^{\circ} \mathrm{C}$ and $2 \mathrm{~h}$ at temperature of $270{ }^{\circ} \mathrm{C}$, respectively. The digests were allowed to cool for $10 \mathrm{~min}$ without dismantling the condensers and then further cooled to room temperature for $10 \mathrm{~min}$ by dismantling the condensers. The mixtures were diluted with $10 \mathrm{~mL}$ of distilled-deionized water and filtered with Whatman filter paper No. 42 into $50 \mathrm{~mL}$ volumetric flasks, respectively. The round bottom flasks were further rinsed with $5 \mathrm{~mL}$ of distilled-deionized water and added to the filtrates and diluted up to the mark with distilled-deionized water.

\section{Calibration procedure}

Standard solutions $(10 \mathrm{mg} / \mathrm{L})$ of metals of interest were prepared from the atomic absorption spectroscopy standard stock solutions that contained $1000 \mathrm{mg} / \mathrm{L}$. The standards were diluted with deionized water to obtain four working standards of each metal, i.e. $\mathrm{Al}, \mathrm{Ca}, \mathrm{Cr}, \mathrm{Cu}, \mathrm{Zn}, \mathrm{Cd}, \mathrm{Ni}$ and $\mathrm{Pb}$. The absorbances of the working standard solutions were measured and the calibration curves for each of the analyte metal ( $\mathrm{Ca}, \mathrm{Cr}, \mathrm{Cu}, \mathrm{Zn}, \mathrm{Ni}$ and $\mathrm{Pb}$ ) were constructed. Calibration curve for each element was constructed using an appropriate standard at a series of concentrations. Regression equation for each metal was constructed and the best fit of the equation was checked using correlation coefficient ( $r$ ). In all the cases, the regression coefficient ( $r$ ) was found to be the accepted linear range value of 0.999 . The calibration curves were with good correlation coefficients. The wavelength, correlation coefficient and calibration curve equation for each metal are given in Table 2.

\section{Detection and quantification limits}

The limit of detection (LOD) is the lowest concentration or weight of analyte that can be measured at a specific confidence level. For the determination of limit of detection of the analytical method (LOD), three blanks were prepared and analyzed for their metal contents. The standard deviation (SD) of the three blanks was calculated and multiplied by three (LOD = 3SD) to determine the method detection limit. The limit of quantification (LOQ) is the smallest quantity of analyte that can be measured with acceptable accuracy and precision and it is described as ten times of the standard deviation. The limit of detection and quantification for all of the nine elements in the plant samples were estimated and are given in Table 2.

\section{Recovery test}

Spiking experiments were performed to validate the optimized procedure. For recovery measurement the Clausena anisata sample from Muger was selected and the spiking was done in triplicate. From the stock standard solution of 1000 $\mathrm{mg} / \mathrm{L}, 34.26 \mu \mathrm{L}$ of $\mathrm{Zn}, 32.79 \mu \mathrm{L}$ of Mn, $14.95 \mu \mathrm{L}$ of Cd, $2.63 \mu \mathrm{L}$

Table 2: The wavelength, method detection and quantification limit, correlation coefficient and calibration curve equations

\begin{tabular}{cccccc}
\hline Metals & $\begin{array}{c}\text { Wavelength } \\
(\mathrm{nm})\end{array}$ & $\begin{array}{c}\text { MDL } \\
(\mathrm{mg} / \mathrm{kg})\end{array}$ & $\begin{array}{c}\text { MQL } \\
(\mathrm{mg} / \mathrm{kg})\end{array}$ & $\begin{array}{c}\text { Correlation } \\
\text { coefficient }(\mathrm{r})\end{array}$ & Calibration curve equation \\
\hline $\mathrm{Al}$ & 396.152 & 0.17 & 0.57 & 0.9999 & $\mathrm{y}=24298 \mathrm{x}+759.36$ \\
$\mathrm{Mg}$ & 279.553 & 0.15 & 0.50 & 0.9994 & $\mathrm{y}=19334 \mathrm{x}+1884.8$ \\
$\mathrm{Cu}$ & 327.395 & 0.40 & 1.3 & 0.9997 & $\mathrm{y}=33562 \mathrm{x}+525.38$ \\
$\mathrm{Mn}$ & 259.372 & 0.02 & 0.07 & 0.9996 & $\mathrm{y}=2977 \mathrm{x}+206.33$ \\
$\mathrm{Ni}$ & 305.081 & 0.27 & 0.90 & 0.9997 & $\mathrm{y}=4453.4 \mathrm{x}+270.29$ \\
$\mathrm{Zn}$ & 213.857 & 0.22 & 0.73 & 0.9995 & $\mathrm{y}=4541.8 \mathrm{x}+301.91$ \\
$\mathrm{Cr}$ & 276.653 & 0.34 & 1.1 & 0.9946 & $\mathrm{y}=327.3 \mathrm{x}+50.34$ \\
$\mathrm{Fe}$ & 371.993 & 0.40 & 1.3 & 0.9995 & $\mathrm{y}=5024.3 \mathrm{x}+203.51$ \\
$\mathrm{Ca}$ & 422.673 & 0.56 & 1.9 & 0.9983 & $\mathrm{y}=67343 \mathrm{x}+21867$ \\
\hline
\end{tabular}

Table 3: Analytical results for recovery test of plant samples

\begin{tabular}{|c|c|c|c|c|c|}
\hline Metal & $\begin{array}{l}\text { Concentration of metal in un- } \\
\text { spiked sample }(\mathrm{mg} / \mathrm{kg})\end{array}$ & \% spiked & $\begin{array}{l}\text { Amount spiked } \\
(\mathrm{mg} / \mathrm{L})\end{array}$ & $\begin{array}{l}\text { Concentration of metal in } \\
\text { spiked sample }(\mathrm{mg} / \mathrm{kg})\end{array}$ & $\begin{array}{c}\text { Recovery } \\
(\%)\end{array}$ \\
\hline $\mathrm{Mg}$ & 119 & 25 & 29.8 & 147 & $94.0 \pm 5.6$ \\
\hline $\mathrm{Cu}$ & 13.1 & 40 & 5.26 & 18.6 & $104 \pm 5.5$ \\
\hline $\mathrm{Mn}$ & 327 & 20 & 65.5 & 388 & $93.1 \pm 5.9$ \\
\hline $\mathrm{Ni}$ & 6.55 & 50 & 3.28 & 9.82 & $99.6 \pm 9.7$ \\
\hline $\mathrm{Zn}$ & 342 & 20 & 68.51 & 412 & $102 \pm 2.8$ \\
\hline $\mathrm{Cr}$ & 7.61 & 50 & 3.84 & 11.2 & $93.4 \pm 7.4$ \\
\hline
\end{tabular}


of $\mathrm{Cu}, 1.92 \mu \mathrm{L}$ of $\mathrm{Cr}$, and $1.64 \mu \mathrm{L}$ of Ni were added to $0.5 \mathrm{~g}$ of Clausena anisata sample. The spiked and non-spiked samples were digested and analyzed in similar condition using the optimized procedure. As shown in Table 3, six metals were analyzed in triplicate standard metal solutions to evaluate the efficiency of the procedure and the percentage recoveries lies within the range from 93.1 to $104 \%$ which are within the acceptable range of $100 \pm 10$ indicating the validity of the analytical procedure used.

\section{RESULTS AND DISCUSSION}

\section{The concentrations of metals in plant samples}

The concentrations of the metals in the three plants samples were determined by MP-AES and precision of the results was determined by calculating the standard deviation (SD). Mean values were determined from triplicate analysis of each sample and triplicate samples were analyzed from each sample site. Thus the mean values determined were from triplicate measurements of triplicate analysis for each metal and the results are reported in terms of mean \pm SD. The results are given in Table 4.

The maximum concentration levels in the plant samples for elements $\mathrm{Al}, \mathrm{Mg}, \mathrm{Cu}, \mathrm{Mn}, \mathrm{Ni}, \mathrm{Zn}, \mathrm{Cr}, \mathrm{Fe}$ and $\mathrm{Ca}$ are $1032,119,17.1,101,452,342,19,3250$ and $27990 \mathrm{mg} / \mathrm{kg}$, respectively. Similarly the minimum concentration levels in the plant samples for the elements $\mathrm{Al}, \mathrm{Cd}, \mathrm{Cu}, \mathrm{Mn}, \mathrm{Ni}, \mathrm{Zn}, \mathrm{Cr}$, $\mathrm{Fe}$ and $\mathrm{Ca}$ are 89.3, 8.08, 11.2, 20.5, 1.95, 108, 2.49, 154 and $10602 \mathrm{mg} / \mathrm{kg}$, respectively.

Higher concentrations of $\mathrm{Ni}$ is observed in the $S$. subserrata samples collected from the Muger sampling site, and relatively lower amounts of $\mathrm{Cr}$ and $\mathrm{Cu}$ are observed compared to that of $\mathrm{Cd}, \mathrm{Mn}$, and $\mathrm{Ni}$ collected from the three sampling sites. Similarly relatively higher concentrations of Ca is observed compared to that of $\mathrm{Fe}, \mathrm{Al}$ and $\mathrm{Zn}$ in the $S$. subserrata samples collected from the three sampling areas. The mean concentrations of the metals $(\mathrm{mg} / \mathrm{kg})$ in the $S$. subserrata samples collected from the three sampling areas are in the order as $\mathrm{Ca}>\mathrm{Fe}>\mathrm{Ni}>\mathrm{Zn}>\mathrm{Al}>\mathrm{Mg}>\mathrm{Mn}>\mathrm{Cu}$.

Higher concentrations of $\mathrm{Zn}, \mathrm{Mn}$ and $\mathrm{Cd}$ is observed in the $S$. cunnefolia samples compared to that of $\mathrm{Cu}, \mathrm{Cr}$, and $\mathrm{Ni}$ collected from the three sampling sites. Similarly relatively higher concentrations of $\mathrm{Ca}$ is observed compared to that of $\mathrm{Fe}$ and $\mathrm{Al}$ in the $S$. cunnefolia samples collected from the three sampling areas. The mean concentrations of the metals $(\mathrm{mg} / \mathrm{kg})$ in the $S$. cunnefolia samples collected from the three sampling areas are in the order as $\mathrm{Ca}>\mathrm{Fe}>$ $\mathrm{Al}>\mathrm{Zn}>\mathrm{Cd}>\mathrm{Mn}>\mathrm{Cu}>\mathrm{Cr}>\mathrm{Ni}$.

Higher concentrations of $\mathrm{Zn}$ is observed in the $C$. anisata samples collected from the Muger sampling site compared to $\mathrm{Zn}$ collected from the three sampling sites, and relatively lower amounts of $\mathrm{Cr}, \mathrm{Ni}$ and $\mathrm{Cu}$ is observed compared to that of $\mathrm{Al}, \mathrm{Cd}$, and $\mathrm{Zn}$ collected from the three sampling sites. Similarly, relatively higher concentration of $\mathrm{Ca}$ is observed compared to that of $\mathrm{Fe}$ in the $C$. anisata samples collected from the three sampling areas. The mean concentrations of the metals $(\mathrm{mg} / \mathrm{kg})$ in the $C$. anisata samples collected from the three sampling areas are in the order as $\mathrm{Ca}>\mathrm{Fe}>\mathrm{Al}>\mathrm{Zn}>\mathrm{Mg}>\mathrm{Mn}>\mathrm{Cu}>\mathrm{Cr}>\mathrm{Ni}$.

As shown in Table 5 the overall mean concentrations of the metals (mg/L) in the $S$. subserrata, $S$. cunnefolia and $C$. anisata samples collected from the three sampling areas can be ordered as $\mathrm{Ca}>\mathrm{Fe}>\mathrm{Al}>\mathrm{Zn}>\mathrm{Mg}>\mathrm{Ni}$ $>\mathrm{Mn}>\mathrm{Cu}>\mathrm{Cr}$. There is significant variation of the mean concentrations of the metals $\mathrm{Al}, \mathrm{Fe}$, and $\mathrm{Ni}$ between the $S$. subserrata, $S$. cunnefolia, and C. anisata samples. But small variations of the mean concentrations of $\mathrm{Cu}, \mathrm{Zn}, \mathrm{Cr}, \mathrm{Ca}, \mathrm{Mn}$ and $\mathrm{Mg}$ are observed between the S. subserrata, S. cunnefolia and $C$. aisata samples collected from the three sampling sites.

\section{Comparison of metals in plant samples with tooth pastes}

The plant samples that are studied in this work are used as traditional toothbrushes and hence the results of this study are compared with the values of some heavy metals determined in nine tooth paste samples reported in the literature. The results are given in Table 6 .

As can be seen from the Table 6 diversified concentration ranges of the studied metals were noticed compared with tooth pastes. The results obtained in this study indicated that $\mathrm{Fe}, \mathrm{Cu}, \mathrm{Mn}$ and $\mathrm{Ni}$ are more in the plant samples, $\mathrm{Zn}$ is more in pastes than in the plant samples, $\mathrm{Cr}$ in the plant samples is comparable with pastes.

\section{Analysis of variance (ANOVA)}

The concept of ANOVA is to compare different sources of variance and make inferences about their relative sizes. In the study one-way ANOVA (one treatment factor with two or

Table 4: Mean concentrations (mean $\pm \mathrm{SD}, \mathrm{n}=3$, $\mathrm{mg} \mathrm{kg}^{-1}$ dry weight) of metals in each sample sites analyzed by MP-AES

\begin{tabular}{|c|c|c|c|c|c|c|c|c|c|c|c|c|}
\hline Sites & Plant & $\mathrm{Al}$ & $\mathrm{Mg}$ & $\mathrm{Cu}$ & $\mathrm{Mn}$ & $\mathrm{Ni}$ & $\mathrm{Zn}$ & $\mathrm{Cr}$ & $\mathrm{Fe}$ & $\mathrm{Ca}$ & $\mathrm{Pb}$ & $\mathrm{Cd}$ \\
\hline \multirow{3}{*}{ Muger } & S. subserrata & a $91.9 \pm 1.0$ & $80.0 \pm 0.5$ & $36.4 \pm 5.5$ & $60.7 \pm 6.5$ & $452 \pm 8.8$ & $147 \pm 6.6$ & $19.0 \pm 2.1$ & $1035 \pm 8.8$ & $16687 \pm 5.0$ & ND & ND \\
\hline & S. cuneifolia & $1032 \pm 8.1$ & $82.8 \pm 6.6$ & $16.0 \pm 2.2$ & $61.3 \pm 2.3$ & $5.64 \pm 0.90$ & $152 \pm 1.7$ & $5.98 \pm 1.7$ & $193 \pm 7.3$ & $26182 \pm 6.4$ & ND & ND \\
\hline & C. Anisata & $104 \pm 7.1$ & $119 \pm 2.9$ & $13.1 \pm 0.9$ & $23.1 \pm 0.4$ & $6.55 \pm 1.27$ & $342 \pm 5.4$ & $7.68 \pm 1.1$ & $3250 \pm 4.9$ & $19285 \pm 4.5$ & ND & ND \\
\hline \multirow{3}{*}{ Sendafa } & S. subserrata & $149 \pm 7.8$ & $52.7 \pm 2.3$ & $12.7 \pm 0.7$ & $61.3 \pm 2.3$ & $7.65 \pm 1.12$ & $281 \pm 4.9$ & $2.49 \pm 0.33$ & $248 \pm 4.6$ & $10602 \pm 2.6$ & ND & ND \\
\hline & S. cuneifolia & $2291 \pm 7.9$ & $104 \pm 5.9$ & $20.4 \pm 1.9$ & $101 \pm 7.6$ & $6.57 \pm 0.49$ & $155 \pm 7.1$ & $7.71 \pm 0.20$ & $2853 \pm 3.7$ & $23569 \pm 6.1$ & ND & ND \\
\hline & C. anisata & $89.3 \pm 3.5$ & $89.3 \pm 3.5$ & $13.2 \pm 0.8$ & $20.5 \pm 0.3$ & $3.51 \pm 0.48$ & $122 \pm 8.6$ & $7.58 \pm 0.36$ & $168 \pm 3.4$ & $16288 \pm 8.5$ & ND & ND \\
\hline \multirow{3}{*}{ Holeta } & S. subserrata & $122 \pm 5.8$ & $76.5 \pm 5.0$ & $11.2 \pm 0.8$ & $23.1 \pm 0.4$ & $19.8 \pm 1.52$ & $108 \pm 4.3$ & $2.49 \pm 0.33$ & $259 \pm 7.2$ & $15161 \pm 8.6$ & ND & ND \\
\hline & S. cuneifolia & $467 \pm 3.3$ & $118 \pm 8.5$ & $17.1 \pm 1.1$ & $71.9 \pm 0.6$ & $3.74 \pm 0.35$ & $148 \pm 5.5$ & $7.71 \pm 0.20$ & $507 \pm 6.2$ & $27990 \pm 8.1$ & ND & ND \\
\hline & C. Anisata & $117 \pm 3.8$ & $84.8 \pm 3.6$ & $13.0 \pm 1.9$ & $31.6 \pm 6.0$ & $1.95 \pm 0.47$ & $123 \pm 6.2$ & $7.58 \pm 0.36$ & $154 \pm 7.2$ & $18834 \pm 6.7$ & ND & ND \\
\hline
\end{tabular}


more treatment levels) was used. One-way ANOVA was used to compare the mean values of the metals between different sample sites. The results of ANOVA indicated that there is significant difference among the mean concentration of $\mathrm{Al}$, $\mathrm{Ca}, \mathrm{Cd}, \mathrm{Cu}, \mathrm{Ni}, \mathrm{Fe}, \mathrm{Zn}, \mathrm{Mn}$ and $\mathrm{Cr}$ found in the three plant samples collected from the three-sampling area at $\mathrm{p}=0.05$ confidence level.

The results of ANOVA indicated that there is a significant difference among the mean concentrations of $\mathrm{Al}$, $\mathrm{Cd}, \mathrm{Cu}, \mathrm{Mn}, \mathrm{Ni}, \mathrm{Zn}, \mathrm{Cr}$, and Fe found in the S. subserrata samples collected from the three sampling areas at $\mathrm{p}=0.05$ confidence level. But there is no significant difference on the mean concentrations of Ca between the $S$. subserrata samples. Similarly, the results of ANOVA indicated that there is a significant difference among the mean concentrations of $\mathrm{Mn}, \mathrm{Ni}, \mathrm{Cr}$, and Fe found in the S. cunnifolia samples collected from the three sampling areas at $\mathrm{p}=0.05$ confidence level. But there is no significant difference on the mean concentrations of $\mathrm{Al}, \mathrm{Cd}, \mathrm{Cu}, \mathrm{Zn}$, and $\mathrm{Ca}$ between the $S$. cunnifolia samples. Finally, the results of ANOVA indicated that there is a significant difference among the mean concentrations of $\mathrm{Cd}, \mathrm{Mn}, \mathrm{Zn}, \mathrm{Fe}$, and $\mathrm{Ca}$ found in the
Clausena anisata samples collected from the three sampling areas at $\mathrm{p}=0.05$ confidence level. But there is no significant difference on the mean concentrations of $\mathrm{Al}, \mathrm{Cu}, \mathrm{Ni}$ and $\mathrm{Cr}$ between the $C$. anisata samples. The presence of significance difference may be due to the presence of different geographical distribution, rainfall, soil composition and climatic conditions.

\section{Pearson correlation}

The Pearson product-moment correlation coefficient is the measure of the strength of a linear association between two variables (Miller and Miller, 2005). A correlation coefficient of +1.0 indicates a perfect positive correlation while a correlation coefficient of -1.0 indicates a perfect negative correlation. The correlation values are categorized as no correlation ( $\mathrm{r}=0.00-0.19)$, low correlation ( $\mathrm{r}=0.20-0.49)$, medium correlation ( $r=0.50-0.75)$, and higher correlation $(r=0.75-1.00)$. Linear regression correlations tests were performed to investigate the correlations between metal concentrations in the three plant samples.

Table 5: Mean concentrations of metals $(\mathrm{mg} / \mathrm{kg})$ in the plant samples collected from the three sampling areas

\begin{tabular}{|c|c|c|c|c|}
\hline Metals & S. subserrata & S. cunnefolia & C. anisata & Overall mean \\
\hline $\mathrm{Al}$ & 121 & 1263 & 103 & 496 \\
\hline $\mathrm{Mg}$ & 46 & 102 & 98 & 82 \\
\hline $\mathrm{Cu}$ & 20 & 18 & 13 & 17 \\
\hline $\mathrm{Mn}$ & 48 & 78 & 25 & 50 \\
\hline $\mathrm{Ni}$ & 160 & 5 & 4 & 56 \\
\hline $\mathrm{Zn}$ & 179 & 152 & 196 & 176 \\
\hline $\mathrm{Cr}$ & 8 & 7 & 8 & 8 \\
\hline $\mathrm{Fe}$ & 514 & 1184 & 1191 & 963 \\
\hline $\mathrm{Ca}$ & 14150 & 25914 & 18136 & 19400 \\
\hline
\end{tabular}

Table 6: Comparison of levels of metals in plant samples with tooth paste (mg/kg) (Vella and Attard, 2019)

\begin{tabular}{llllll}
\hline Sample & $\mathrm{Cr}$ & $\mathrm{Cu}$ & $\mathrm{Ni}$ & $\mathrm{Zn}$ & $\mathrm{Fe}$ \\
\hline *Tooth pastes & $0.28-7.35$ & $0.73-3.68$ & $0.43-2.54$ & $1842-2417$ & $1.76-17.68$ \\
Plant samples of this & $7-8$ & $13-20$ & $4-160$ & $152-196$ & $0.20-2.07$ \\
study & & & & M14-1191
\end{tabular}

study

*Included conventional, herbal and children's toothpastes

Table 7: Pearson correlation coefficients of the metals in the three plant samples

\begin{tabular}{lllllllll}
\hline & $\mathrm{Al}$ & $\mathrm{Mg}$ & $\mathrm{Cu}$ & $\mathrm{Mn}$ & $\mathrm{Ni}$ & $\mathrm{Zn}$ & $\mathrm{Cr}$ & $\mathrm{Fe}$ \\
$\mathrm{Al}$ & 1.00 & & & & & & \\
$\mathrm{Mg}$ & 0.54 & 1.00 & & & & & \\
$\mathrm{Cu}$ & 0.25 & -0.67 & 1.00 & & & & \\
$\mathrm{Mn}$ & 0.91 & 0.14 & 0.64 & 1.00 & & & \\
$\mathrm{Ni}$ & -0.48 & -1.00 & 0.72 & -0.07 & 1.00 & & & \\
$\mathrm{Zn}$ & -0.93 & -0.19 & -0.59 & -1.00 & 0.12 & 1.00 & & \\
$\mathrm{Cr}$ & -1.00 & -0.55 & -0.24 & -0.90 & 0.50 & 0.92 & & \\
$\mathrm{Fe}$ & 0.48 & 1.00 & -0.73 & 0.07 & -1.00 & -0.12 & -0.49 & 1.00 \\
$\mathrm{Ca}$ & 0.94 & 0.80 & -0.10 & 0.71 & -0.76 & -0.74 & -0.94 & 0.75 \\
\hline
\end{tabular}


Pearson correlation was evaluated for the overall mean concentration of the individual metals in the three plants. The results are given in Table 7. Accordingly wide variations in the pairs of metals are observed. Some pairs of metals show no correlation, some pairs show low correlation, some pairs show medium correlation and some pairs show higher correlation. The correlations also varied in sign some pair showed positive correlations while others showed negative correlations. There was a similar pattern for the individual plant.

\section{CONCLUSIONS}

The overall mean concentrations of the metals (mg/kg) in the Salix subserrata, Sida cunnefolia, and Clausena anisata samples collected from the three sampling areas was in the order of: $\mathrm{Ca}$ $(14150-25914)>\mathrm{Fe}(514-1191)>\mathrm{Al}(103-1263)>\mathrm{Zn}(152-$ 196) $>\mathrm{Mg}(46-102)>\mathrm{Ni}(4-160)>\mathrm{Mn}(25-78)>\mathrm{Cu}(13-20)>$ Cr (7-8). From the results of this work, it is possible to conclude that the plant samples collected from the three sites accumulated relatively larger amounts of $\mathrm{Ca}$ and $\mathrm{Fe}$ among the determined metals and lower amounts of $\mathrm{Cu}, \mathrm{Cr}$ and $\mathrm{Mn}$. ANOVA indicated that there is no significance difference between the mean concentrations of $\mathrm{Ca}$ among the $S$. subserrata samples, of $\mathrm{Mg}, \mathrm{Cu}, \mathrm{Zn}$ and $\mathrm{Ca}$ among the $S$. cunnefolia samples and of $\mathrm{Al}, \mathrm{Cu}, \mathrm{Cr}$, and $\mathrm{Ni}$ among the $C$. anisata samples, but there is a significant difference for the other studied metals among the corresponding plant samples at $95 \%$ confidence level. Since the toxic metals $\mathrm{Cd}$ and $\mathrm{Pb}$ in the plant samples were not detected, it is possible to conclude that people who use tooth brush from the three plants are free from the risks of $\mathrm{Cd}$ and $\mathrm{Pb}$ toxicity.

\section{ACKNOWLEDGEMENTS}

The authors express their gratitude to the Department of Chemistry, Addis Ababa University, Ethiopia for providing the laboratory facilities. Wubalem Entele is thankful to Addis Ababa Educational Bureau, Ethiopia for sponsoring his study.

\section{REFERENCES}

Abdella, A., Chandravanshi, B.S., Yohannes, W., 2018. Levels of selected metals in coriander (Coriandrum sativum L.) leaves cultivated in four different areas of Ethiopia. Chemistry International 4, 189-197.

Admasu, S., Chandravanshi, B.S., Yohannes, W., 2018. Levels of selected metals in the leaves of Ruta chalepensis L. (Rue) collected from four different areas of Ethiopia. Bulletin of the Chemical Society of Ethiopia 32, 185-197.

Akpata, E.S., Akinrimisi, E.O., 1977. Antimicrobial activity of extracts from some African chewing sticks. Oral Surgery, Oral Medicine, Oral Pathology 44, 717-722.

Al-hebshi, N., Al-haroni, M., Skaug, N., 2006. In vitro antimicrobial and resistance modifying activities of aqueous crude khat extracts against oral microorganisms. Archives of Oral Biology 51, 183-188.
Almas, K., 1999. The antimicrobial effects of extracts of Azadirachta indica (Neem) and Salvadora persica (Arak) chewing sticks. Indian Journal of Dental Research 10, 2326.

Almas, K., 2001. The antimicrobial effects of seven different types of Asian chewing sticks. Odonto-stomatologie Tropicale 24, 17-20.

Atlabachew, M., Chandravanshi, B.S., Redi, M., 2010. Concentration levels of essential and non-essential metals in Ethiopian khat (Catha edulis Forsk). Biological Trace Element Research 138, 316-325.

Başgel, S., Erdemoğlu, S.B., 2006. Determination of mineral and trace elements in some medicinal herbs and their infusions consumed in Turkey. Science of the Total Environment 359, 82-89.

Bin, C., Xiaoru, W., Lee, F.S.C., 2001. Pyrolysis coupled with atomic absorption spectrometry for determination of mercury in Chinese medicinal materials. Analytica Chimica Acta 447, 161-169.

Derbie, A., Chandravanshi, B.S., 2011. Concentration levels of selected metals in the leaves of different species of thyme (T. schimperi and T. vulgaris) grown in Ethiopia. Biological Trace Element Research 141, 317-328.

Dubale, A.A., Chandravanshi, B.S., Gebremariam, K.F., 2015. Levels of major and trace metals in the leaves and infusions of Croton macrostachyus. Bulletin of the Chemical Society Ethiopia 29, 11-26.

Fadulu, S.O., 1975. The antibacterial properties of the buffer extracts of chewing sticks used in Nigeria. Planta Medica 27, 122-126.

Gebre, A., Chandravanshi, B.S., 2012. Levels of essential and non-essential metals in Rhamnus prinoides (Gesho) cultivated in Ethiopia. Bulletin of the Chemical Society Ethiopia 26, 329-342.

Hagos, M., Chandravanshi, B.S., 2016. Levels of essential and non-essential metals in fenugreek seed (Trigonella Foenum-Graecum L.) cultivated in different parts of Ethiopia. Brazilian Journal of Food Technology 19, e2015059.

Hamza, 0.J.M., van den Bout-van den Beukel, C.J.P., Matee, M.I.N., Moshi, M.J., Mikx, F.H.M., Selemani, H.O., Mbwambo, Z.H., Van der Ven, A.J.A.M., Verweij, P.E., 2006. Antifungal activity of some Tanzanian plants used traditionally for the treatment of fungal infections. Journal of Ethnopharmacology 108, 124-132.

Homer, K.A., Manji, F., Beighton, D., 1990. Inhibition of protease activities of periodontopathic bacteria by extracts of plants used in Kenya as chewing sticks [mswaki]. Archives of Oral Biology 35, 421-424.

Hutchings, A., Scoh, A.H., Lewis, G., Cunningham, A., 1996. Clausena anisata (Wild). Hook. F. ex Benth, Zulu medicinal plants: An inventory. University of Natal Press, Pietermaritzbury, South Africa, 1, 153-154.

Kassu, A., Dagne, E., Abate, D., De Castro, A., van Wyk, B.-E., 1999. Ethnomedical aspects of the commonly used toothbrush sticks in Ethiopia. East African Medical Journal 76, 651-653. 
Kemoli, A.M., van Amerongen, W.E., de Soet, J.J., 2001. Antimicrobial and buffer capacity of crude extracts of chewing sticks (Miswaki) from Kenya. Journal of Dentistry for Children 68, 183-188.

Lawal, I.O., Grierson, D.S., Afolayan, A.J., 2014. Phytotherapeutic information on plants used for the treatment of tuberculosis in eastern Cape Province, South Africa. Evidence-Based Complementary and Alternative Medicine, 2014, 735423.

Mekebo, D., Chandravanshi, B.S., 2014. Levels of essential and non-essential metals in linseed (Linum usitatissimum) cultivated in Ethiopia. Bulletin of the Chemical Society Ethiopia 28, 349-362.

Miller, J.N., Miller, J.C., 2005. Statistics and chemometrics for analytical chemistry, 5th ed., Pearson Practice Hall, England.

Niazi, F., Naseem, M., Khurshid, Z., Zafar, M.S., Almas, K., 2016. Role of Salvadora persica chewing stick (miswak): A natural toothbrush for holistic oral health.European Journal of Dentistry 10, 301-308.

Ojewole, J.A.O., 2002. Hypoglycaemic effect of Clausena anisata (Willd) Hook methanolic root extract in rats. Journal of Ethnopharmacology 81, 231-237.

Olsson, B., 1978. Efficiency of traditional chewing sticks in oral hygiene programs among Ethiopia schoolchildren. Community Dentistry and Oral Epidemiology 6,

105-109. Salim, R., Al-Subu, M.M., Atallah, A., 1993. Effects of root and foliar treatments with lead, cadmium, and copper on the uptake distribution and growth of radish plants. Environment International 19, 393-404.

Senthikumar, A., Venkatesalu, V., 2009. Phytochemical analysis and antibacterial activity of the essential oil of Clausena anisata (Willd.) hook. f. ex benth. International Journal of Integrative Biology 5, 116-120.

Singh, R.P., Tripathi, R.D., Sinha, S.K., Maheshwari, R., Srivastava, H.S., 1997. Response of higher plants to lead contaminated environment. Chemosphere 34. 2467-2493.

Vella, A., Attard, E., 2019. Analysis of heavy metal content in conventional and herbal toothpastes available at Maltese Pharmacies. Cosmetics 6, 28.

Wagesho, Y., Chandravanshi, B.S., 2015. Levels of essential and non-essential metals in ginger (Zingiber officinale) cultivated in Ethiopia. Springer Plus 4, 107.

Wu, C.D., Darout, I.A., Skaug, N., 2001. Chewing sticks: Timeless natural toothbrushes for oral cleansing. Journal of Periodontal Research 36, 275-284.

York, T., van Vuuren, S.F., De Wet H., 2012. An antimicrobial evaluation of plants used for the treatment of respiratory infections in rural Maputaland, KwaZulu-Natal, South Africa. Journal of Ethnopharmacology 144, 118-127.

Zerihun, A., Chandravanshi, B.S., Debebe, A., Mehari, B., 2015. Levels of selected metals in leaves of Cannabis sativa $\mathrm{L}$. cultivated in Ethiopia. Springer Plus 4, 359.

Visit us at: http://bosaljournals.com/chemint/ Submissions are accepted at: editorci@bosaljournals.com 